\title{
Provenancing Baltic timber from art historical objects: success and limitations
}

\author{
K. Haneca ${ }^{\mathrm{a}, *}$, T. Wazny ${ }^{\mathrm{b}, 1}$, J. Van Acker ${ }^{\mathrm{a}}$, H. Beeckman ${ }^{\mathrm{c}, 2}$ \\ ${ }^{\mathrm{a}}$ Ghent University, Department of Forest and Water Management, Laboratory of Wood Technology, \\ Coupure Links 653, 9000 Gent, Belgium \\ ${ }^{\mathrm{b}}$ Nicolaus Copernicus University, Institute for the Study, Conservation and Restoration of Cultural Heritage, \\ Laboratory of Dendrochronological Research, Ul. Sienkiewicza 30/32, 87-100 Torun, Poland \\ ${ }^{\mathrm{c}}$ Africamuseum, Laboratory for Wood Biology and Xylarium, Leuvensesteenweg 13, 3080 Tervuren, Belgium
}

Received 18 March 2004; received in revised form 1 September 2004

\begin{abstract}
During the Middle Ages northern Belgium and The Netherlands were gradually deforested. A steadily rising demand for quality timber obliged merchants to look for new timber sources. From the 13th century onwards, large volumes of timber were imported from surrounding regions and, despite the remote supply area, merchants of the Hanseatic League managed to organize a huge timber trade from towns around the Baltic Sea.

Trees from forests along the Vistula River seem to have been exported via Gdansk, first to Bruges and later to Antwerp. At their final destination the imported wood assortments were highly appreciated for shipbuilding and construction purposes, but also by woodcarvers and famous painters.

Over the last decade dendrochronologists have established a dense network of historical site chronologies for northern and central Poland. These site chronologies are supposed to reflect local growth conditions and may allow the identification of the provenance of the wood of many art historical objects made out of Baltic timber.

Tree-ring patterns of panel paintings and sculptures, mainly from the 14th-16th centuries, were measured and compared to this data set of site chronologies. An evaluation of the accuracy of sourcing medieval Baltic timbers using standard correlation techniques was made. The identification of provenance enriches historical information on logging activity and timber trade around the Baltic Sea during the Middle Ages.
\end{abstract}

(C) 2004 Elsevier Ltd. All rights reserved.

Keywords: Dendrochronology; Baltic timber; Quercus sp.; Timber trade; Provenance

\section{Introduction}

Forests in the Low Countries experienced a long and complex history of exploitation and degradation. An

\footnotetext{
* Corresponding author. Tel.: + 32926461 24; fax: +3292646233

E-mail addresses: kristof.haneca@ugent.be (K. Haneca), twazny@ mercury.ci.uw.edu.pl (T. Wazny), joris.vanacker@ugent.be (J. Van Acker), hans.beeckman@africamuseum.be (H. Beeckman).

${ }^{1}$ Tel.: +485661138 25; fax: +4556 6224977 .

2 Tel.: + 32276956 11; fax: +3227670242.
}

increasing anthropogenic pressure during the Middle Ages resulted in a drastic deforestation. Major parts of the remaining primary forests were logged and converted to arable land $[8,30]$. As well as a dramatic reduction in forest-cover, management interventions often altered the structure of the residual forests. Sylvicultural systems such as coppice or coppice-with-standards became gradually more popular during the Middle Ages [28,33]. These two structural interventions were often implemented for oak (Quercus robur L. and Quercus petraea (Matt.) Liebl.). Such forests provided a sustainable and 
diverse assortment of timber but were chiefly appreciated for their vigorous production of acorns, which was the most essential source of fodder for pig husbandry.

These changes in forest-cover and structure also had a significant influence on the availability and quality of timber products. The mounting demographic evolution during the Middle Ages resulted in a rising need for construction timber [8]. Local forests could no longer cope with this increased demand. As a consequence, merchants started to explore more remote areas to replenish their supplies. Firewood and wood for carpentry was generally still dependent on the local wood supply, but high quality construction timber was imported from more distant regions.

In general, the most viable wood resources were located along the major rivers of northern Europe (Fig. 1). Water transport was the most economical way to deliver goods. Transport of wood assortments over land, on the other hand, was too laborious and expensive [27]. Trees from forests near a river were cut, cleaved and floated down the river towards a town with the status of staple town and the right to stock and distribute all imported timber passing through [14]. In the Low Countries the Meuse and the Rhine were the most important trade-routes for the shipment of timber products. Forests in Northern France and Germany were the most obvious timber resources since these were the nearest forests where quality timber could be found. However, traditionally Flemish towns have always relied more on overseas transport for their commodities on the international market than transport along the rivers. Timber importation was more convenient by boat, due to the cities close location to the North Sea, than importation of timbers floated along the Rhine or the Meuse that then needed additional transport over land. Also important were the advances in navigation and shipbuilding during the 15 th and 16 th centuries. The Hanseatic cog and hulk, which could carry a cargo of ca. 100 and 300 tons, respectively, enabled the transportation of goods at a massive scale. Political reasons may also have played an important role in the establishment of trading-routes.

During the Middle Ages the Hanseatic League slowly evolved from a loose network of traders to a disciplined organization, controlling most of the trade in Northern Europe. Although exploiting remote areas around the Baltic Sea, the Hansa towns of Lübeck and Gdansk managed to organize a huge trade in Baltic timber [31]. Forests situated along the Vistula River, the main waterway of the medieval kingdom of Poland and Teutonic Order, were the most important exploitation areas for this trade. After logging, stems were cleaved and floated towards the harbour of export. Transportation of semi-products (confirmed e.g. by the records from custom chambers of Wloclawek and Weissberg [29], both located along the Vistula River) was much more convenient and faster than floating complete logs, especially in the case of relative heavy oak stems. During the 14th-15th centuries Gdansk became one of the most important export harbours [5,37]. Later, during the second half of the 16th century, the centre of the timber trade shifted further eastwards, towards Königsberg, Courland and Riga [39].

From early 13th century onwards, oak from the Baltic area was imported into Flanders (northern Belgium). Wood was shipped from the harbour of Gdansk to the harbour of Bruges. At that time Bruges was the commercial centre of Western Europe. It was the meeting point for traders from Italy and Northern Europe $[31,37]$. Later Antwerp gradually started to play a more important role in the timber trade. The oldest physical proof of Baltic timber in Flanders was found on archaeological sites as herring vessels, with felling dates situated at the end of the 14th century [23]. Although shipbuilding was the main branch of industry that used imported timbers, famous painters such as Jan van Eyck (ca. $1395^{\circ}-1441^{\dagger}$ ), Hiëronimus Bosch (ca. $1450^{\circ}-1516^{\dagger}$ ), Pieter Bruegel the Elder (ca. $1525^{\circ}-1569^{\dagger}$ ) and Pieter Paul Rubens $\left(1577^{\circ}-1640^{\dagger}\right)$ highly appreciated the imported oak panels for their paintings $[4,18]$. Also

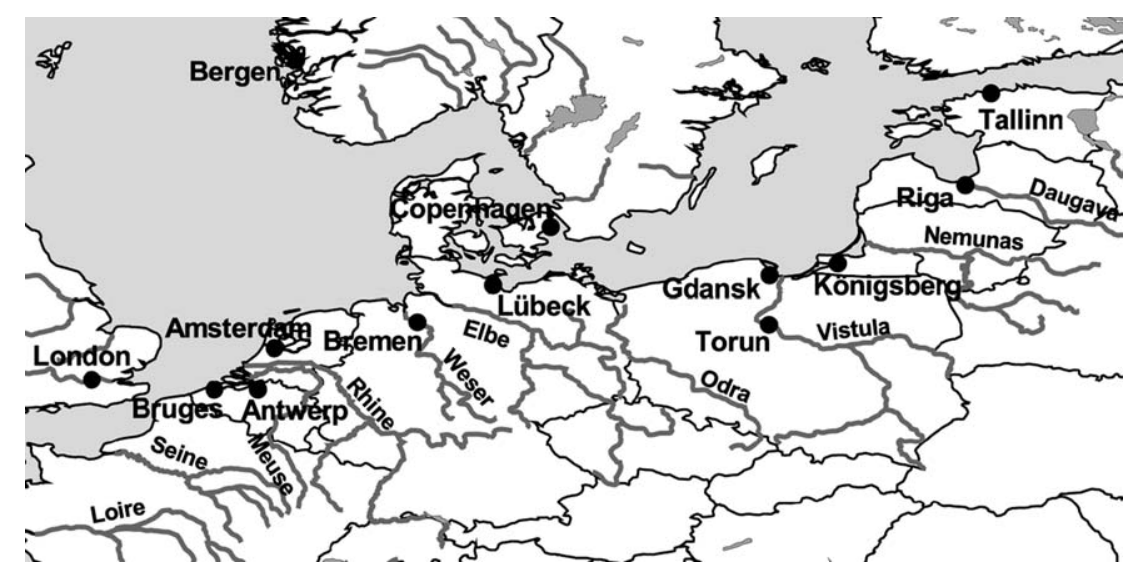

Fig. 1. Major rivers of northern Europe. Primary forests along these waterways are possible historical timber sources. 
wood carvers during the 15th-16th centuries mostly used imported massive planks, referred to as wainscots, to carve their sculptures from. Oak imported from forests covering the Baltic countries was characterized by a slow and regular growth that results in wood with a fine grain (i.e. a narrow tree-ring structure). This has implications regarding the woods' technological properties. A fine grain, combined with a sawing pattern perpendicular to the growth rings (i.e. quarter-sawn timber), delivers boards and panels with a high dimensional stability. In addition to the superior quality, a wide spectrum of different assortments was available. Only a few artists still used local material [20].

Several methods display a high potential for producing information on the original timber source. Recent developments in genetic research have shown the potential of DNA analysis to identify the geographical origin of wood specimens [15]. Optimisation of the polymerase chain reaction (PCR) allows extraction and amplification of short and degraded DNA sequences from modern and ancient oak wood [16]. In the case of $Q$. robur and $Q$. petraea detailed reference maps of chloroplast variants exist for Europe [11,25], and could help to determine the geographical origin of the oak wood. Notwithstanding the new developments, routine implementation of these new techniques to analyse the degraded DNA remains in old, dry wood has yet to be established.

Using dendrochronology to determine the origin of timber has been successfully applied since the development of regional oak chronologies in Europe. This socalled dendro-provenancing is mostly used for wood from an archaeological or art historical context $[5,6,10]$. Within the framework of dendro-provenancing different types of tree-ring chronologies can be distinguished. A site chronology is composed of synchronised tree-ring series from one particular site, where a site is defined on ecological grounds [24]. For historical studies, tree-ring series originating from archaeological sites should be incorporated into this definition. Master or regional chronologies are composed of archaeological, art historical and/or modern tree-ring series. They span long periods and reflect the average growth conditions over a vast area. They are computed by averaging several site chronologies into one series. The master and regional chronologies are mostly used to date new tree-ring series.

When examining tree-ring patterns from historical art objects, up to now the Baltic region was often designated as the original timber source. Although these statements make sense and are well confirmed by historical documents and toll records, they refer to a vast region along the Baltic Sea. Over the last 15 years, the network of site and regional chronologies has been significantly enhanced for countries around the Baltic Sea. Northern and central Poland is now particularly well represented by a large number of historical site chronologies (Wazny, unpublished data). These site chronologies are derived from oak samples found on archaeological sites. They cover a time span between $952 \mathrm{AD}$ and 1670 AD. It is assumed that this wood, used in constructions and foundations, is likely to be local wood. While wood for export was floated down the Vistula, directly towards the towns of the Hanseatic League, wood for local use was cut and cleaved in the nearest forest. These historical site chronologies are supposed to reflect local growth conditions in contrast to the frequently used master chronologies that are composed of tree-ring series from a distinct, but vast area. Well known Baltic master chronologies, computed from tree-ring series of art historical objects, were built by Bauch [2] and Eckstein et al. [18]. Using tree-ring series measured on panel paintings Hillam and Tyers [21] established the Baltic1 and Baltic2 chronologies. For dating purposes these master chronologies have proved to be extremely useful. The Gdansk-Pomerania chronology [19] was the first regional chronology for the Baltic region. It is composed of tree-ring series from buildings and archaeological sites in northern Poland, particularly from the area around Gdansk.

More detailed information on the provenance of Baltic oak, used for the construction of historical art objects, would enrich historical information on logging activity and timber trade in the Baltic region during the Middle Ages. The question arises whether dendrochronology could serve as a tool to determine the original timber source of historical art objects and, most of all, how accurately this timber source can be identified.

\section{Materials and methods}

\subsection{Site and regional chronologies}

Over the last decade dendrochronologists have established a dense network of regional and site chronologies in particular parts of the Baltic region [36]. Archaeological excavations are often the main source of wood samples that are suitable for dendrochronological research. Oak was usually one of the most prominent species used for construction purposes. It is believed that on many of these archaeological sites local forests were the main timber source. This assumption that most of the wood comes from the vicinity of that archaeological site implies that each of the historical site chronologies reflect the local forest dynamics and growth conditions over a certain period. They are supposed to represent the average growth pattern from a single locality.

Site chronologies for 36 archaeological sites (Fig. 2), in present-day Poland, are available for further investigation. The historical site chronologies cover different periods and are derived from a variable number of tree-ring series. Often less than 15 specimens per site were available to compute the site chronology (Table 1). 


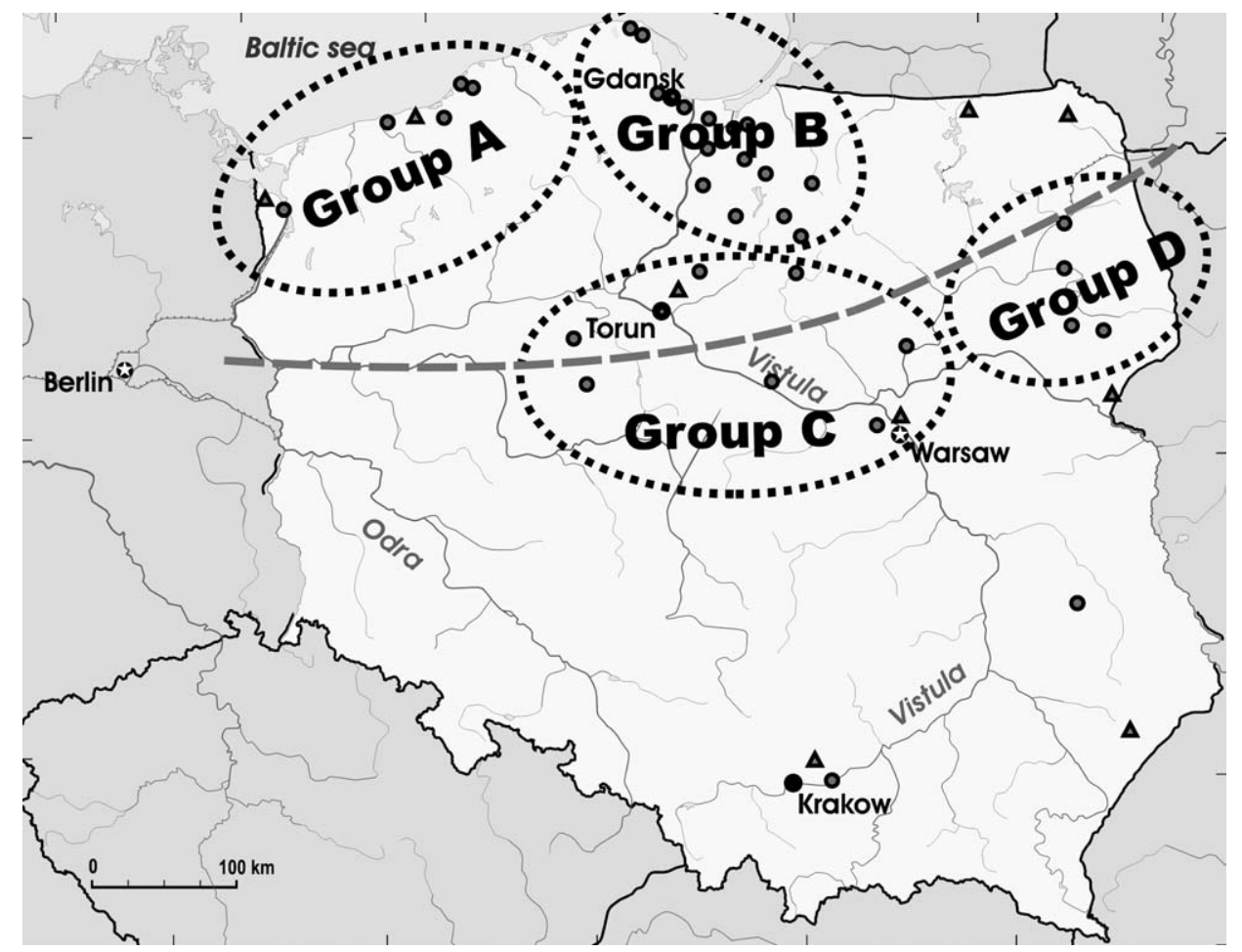

Fig. 2. Location of the archaeological sites $(\bullet)$ and the selected modern forest $(\boldsymbol{\Delta})$, plus a visualization of the regions represented by one of the four dendro-groups. The hatched line indicates the division between northern and southern Poland suggested by Wazny and Eckstein [38].

The archaeological sites are mainly situated in northern and central Poland. Tree-ring data from southern Poland are only available for a few sites.

\subsection{Dendrochronological database of historical art objects}

During an interdisciplinary research project more than 100 wooden sculptures from Brabantine altarpieces, all made out of oak, were submitted for tree-ring analysis [13]. These sculptures were carved during the 15th-16th centuries, mainly in the towns of Antwerp and Brussels. Rich collections of such altarpieces are still preserved in museums all over Europe [12]. This data set of tree-ring series was increased by approximately 100 similar measurements on altarpieces from that period (Bonde, pers. comm. and [34]). In addition more than 300 tree-ring series, from panel paintings, were added to this dendrochronological data set of tree-ring series from historical art objects (Table 2). All the selected works of art were created during the period in which vast amounts of Baltic timber were imported into the Low Countries. In total 390 tree-ring series were available for further analysis.

\subsection{Confronting individual series and references}

In order to compare the individual tree-ring series from the art historical database with the historical site chronologies from Poland, $t$-values were calculated according to the Hollstein algorithm [22]. While calculating these correlation measures, the initial tree-ring data undergo a logarithmic transformation to eliminate age trends.

$y_{i}($ Holl $)=\log \left(\frac{y_{i}}{y_{i+1}}\right)$

The corresponding $t_{\mathrm{H}}$-value between the art historical tree-ring series (sample) and the site chronology (reference) is then calculated as:

$t_{\mathrm{H}}=\frac{r \sqrt{n-2}}{\left(1-r^{2}\right)}$

with

$y_{i}=$ ring width value at year $i$

$y_{i}($ Holl $)=$ tree-ring indices at year $i$, after Hollstein transformation

$r=$ correlation coefficient between sample and reference

$n=$ number of overlapping years between sample and reference

The resulting correlation matrix of $t_{\mathrm{H}}$-values is supposed to provide more detailed information on the provenance of the wood. Theoretically, a high correlation value should be observed when comparing 
Table 1

Description of the selected historical and modern site chronologies from present-day Poland

\begin{tabular}{|c|c|c|c|c|c|}
\hline Site code & $\begin{array}{l}\text { Site } \\
\text { location }\end{array}$ & $\begin{array}{l}\text { Covered } \\
\text { time period } \\
(\mathrm{AD} / \mathrm{BC})\end{array}$ & Length & $\begin{array}{l}\text { Sample } \\
\text { depth }\end{array}$ & Author \\
\hline \multicolumn{6}{|c|}{ Historical site chronologies } \\
\hline Pl-07 & Bielsk Podl. & $1262-1503$ & 242 & 5 & T. Wazny \\
\hline Pl-16 & Bransk & $1247-1427$ & 181 & 16 & T. Wazny \\
\hline Pl-11 & Darlowo & $1477-1670$ & 194 & 5 & T. Wazny \\
\hline Pl-15 & Dabrowno & 1079-1344 & 266 & 10 & T. Wazny \\
\hline $\mathrm{Pl}-31$ & Elblag & $980-1347$ & 368 & 74 & T. Wazny \\
\hline $\mathrm{Pl}-42$ & Gdansk & $1121-1398$ & 278 & 6 & T. Wazny \\
\hline $\mathrm{Pl}-03$ & Izdebno & $1182-1294$ & 113 & 16 & T. Wazny \\
\hline $\mathrm{Pl}-36$ & Jeziernik & $1151-1363$ & 213 & 12 & T. Wazny \\
\hline $\mathrm{Pl}-22 \mathrm{~b}$ & Kolobrzeg & 1509-1664 & 156 & 6 & T. Wazny \\
\hline $\mathrm{Pl}-22 \mathrm{a}$ & Kolobrzeg & 1084-1393 & 310 & 154 & T. Wazny \\
\hline Pl-01b & Koszalin & $1276-1478$ & 203 & - & T. Wazny \\
\hline Pl-01a & Koszalin & $1139-1297$ & 159 & 3 & T. Wazny \\
\hline Pl-12 & Krupy & $1209-1401$ & 193 & 7 & T. Wazny \\
\hline $\mathrm{Pl}-34$ & Kwidzyn & $1343-1587$ & 245 & 6 & T. Wazny \\
\hline $\mathrm{Pl}-35$ & Kwietniewo & $1439-1638$ & 200 & 8 & T. Wazny \\
\hline $\mathrm{Pl}-08$ & Lodygowo & $1206-1308$ & 103 & 2 & T. Wazny \\
\hline $\mathrm{Pl}-29$ & Lubawa & $1476-1610$ & 135 & 4 & T. Wazny \\
\hline Pl-10 & Lublin & $1240-1374$ & 135 & 10 & T. Wazny \\
\hline $\mathrm{Pl}-05$ & Malbork & $1185-1320$ & 136 & 5 & T. Wazny \\
\hline Pl-06 & Nowy Dwor & $1144-1252$ & 109 & 3 & T. Wazny \\
\hline $\mathrm{Pl}-38$ & Gdansk Oliwa & $1375-1599$ & 225 & 12 & T. Wazny \\
\hline Pl-19 & Ostroda & 1157-1346 & 190 & 4 & T. Wazny \\
\hline Pl-09 & Ostrowite & $1133-1299$ & 167 & 2 & T. Wazny \\
\hline $\mathrm{Pl}-20$ & Plock & $1177-1364$ & 188 & 2 & T. Wazny \\
\hline pl-37 & Pruszcz & $1151-1431$ & 281 & - & T. Wazny \\
\hline Pl-39 & Przezmark & $1140-1390$ & 251 & 10 & T. Wazny \\
\hline $\mathrm{Pl}-30$ & Puck & $1408-1568$ & 161 & 8 & T. Wazny \\
\hline $\mathrm{Pl}-41$ & Puck & $1111-1407$ & 297 & 7 & T. Wazny \\
\hline $\mathrm{Pl}-27$ & Pultusk & $1192-1452$ & 261 & - & M. Krapiec \\
\hline $\mathrm{Pl}-04$ & Rusiec & $1236-1447$ & 212 & 23 & T. Wazny \\
\hline $\mathrm{Pl}-40$ & Starzyno & $1147-1374$ & 228 & - & T. Wazny \\
\hline Pl-18 & Szczecin & $952-1272$ & 321 & 74 & T. Wazny \\
\hline $\mathrm{Pl}-44$ & Torun & $1225-1445$ & 221 & - & A. Zielski \\
\hline $\mathrm{Pl}-17$ & Trzemeszno & $1218-1300$ & 83 & 2 & T. Wazny \\
\hline $\mathrm{Pl}-02$ & Tykocin & $1293-1477$ & 185 & 4 & T. Wazny \\
\hline $\mathrm{Pl}-28$ & Vistula & $1100-1529$ & 430 & 25 & M. Krapiec \\
\hline $\mathrm{Pl}-14$ & Zalewo & $1194-1361$ & 168 & 3 & T. Wazny \\
\hline \multicolumn{6}{|c|}{ Tree-ring series from actual Polish forests } \\
\hline pola007 & Goldap & $1871-1980$ & 110 & 22 & T. Wazny \\
\hline pola008 & Hajnowka & $1720-1984$ & 265 & 19 & T. Wazny \\
\hline pola009 & Kosobudy & $1782-1988$ & 207 & 22 & T. Wazny \\
\hline pola010 & Koszalin & $1782-1986$ & 205 & 22 & T. Wazny \\
\hline pola011 & Krakow & $1792-1985$ & 194 & 29 & T. Wazny \\
\hline pola013 & Suwalki & $1861-1986$ & 126 & 19 & T. Wazny \\
\hline pola014 & Torun & $1713-1986$ & 274 & 21 & T. Wazny \\
\hline pola015 & Warszawa & $1690-1984$ & 295 & 19 & T. Wazny \\
\hline pola016 & Wolin & 1554-1986 & 433 & 23 & T. Wazny \\
\hline
\end{tabular}

an individual tree-ring series with a site chronology that is composed of tree-ring series originating from the same area. A threshold value can be set arbitrarily, supported by personal experience, or by consulting tree-ring series from modern trees, growing under comparable conditions in the same climatological region. Modern tree-ring series were selected from nine different sites scattered all over present-day Poland (Fig. 2), but within the same geographical range of the historical sites chronologies. For each site the average $t_{\mathrm{H}}$-value was computed by calculating the $t_{\mathrm{H}}$-values for all possible combinations between trees. The average $t_{\mathrm{H}}$-value for all of the nine modern sites could be used as a threshold for the comparison of medieval tree-ring series with the historical site chronologies.

Nevertheless, it is possible that, while comparing an individual tree-ring series with several site chronologies, more than one $t$-value exceeds the selected threshold. In such cases it is important to take into account the geographical distribution of the matching sites. If one individual site chronology, or a small group of neighbouring sites, display $t$-values higher than the selected threshold, it is assumed that these locations approach the original timber source. On the other hand, if high $t$-values are associated with widely dispersed sites, no further conclusions or interpretation can be made.

\subsection{Grouping sites and individual series}

It is expected that in some cases the comparison of site chronologies with individual tree-ring series will result in correlation values lower than the selected threshold. This could indicate that: (a) the original timber source is not represented by one of the site chronologies, (b) the period spanned by the site chronology does not overlap with the individual series, (c) the presence of growth anomalies within the individual treering series from the database with historical art objects, or (d) that the average growth conditions for that specific area are not well represented by the available site chronology. The latter could be a consequence of a site chronology being composed of only a low number of individual series. To address this problem, neighbouring site chronologies can be grouped into a regional chronology, reflecting average growth conditions for a more extensive region.

When grouping neighbouring site chronologies into one regional chronology it is possible to use all the individual samples incorporated in the separate site chronologies, or treat the site chronologies as individuals and calculate the regional chronology as the arithmetic mean of all site chronologies. In this case the latter should be preferred since the number of treering series that constitute the individual site chronologies from Poland is highly variable and ranges from 3 up to more than 150 (Table 1). Averaging all individual series into one regional chronology would bias the resulting chronology towards the site with the largest number of individual series. This method should increase the strength of the common signal in the calculated chronology, but implies a loss of detail, since 
Table 2

Overview of the art historical database

\begin{tabular}{|c|c|c|c|c|c|}
\hline Object & Total number & Dated & Undated & $\begin{array}{l}\text { Covered time } \\
\text { period (AD) }\end{array}$ & Author(s) \\
\hline \multicolumn{6}{|l|}{ Sculptures from altarpieces } \\
\hline $\begin{array}{l}\text { Altarpieces of Bassine, Pailhe \& } \\
\text { Gaasbeek (Belgium-Brussels) }\end{array}$ & 91 & 62 & 29 & $1203-1515$ & $\begin{array}{l}\text { K. Haneca \& } \\
\text { H. De Pauw }\end{array}$ \\
\hline $\begin{array}{l}\text { Altarpiece fragments from the } \\
\text { Royal Museum of Art and History } \\
\text { (Belgium-Brussels) }\end{array}$ & 11 & 4 & 7 & $1188-1502$ & K. Haneca \\
\hline $\begin{array}{l}\text { Altarpiece fragments from the } \\
\text { Museum Vleeshuis (Belgium-Antwerp) }\end{array}$ & 19 & 17 & 2 & $1206-1526$ & K. Haneca \\
\hline $\begin{array}{l}\text { Altarpieces of Holstebro \& } \\
\text { Ulkebol (Denmark) }\end{array}$ & 7 & 7 & - & $1181-1495$ & N. Bonde \\
\hline Other altarpiece fragments & 91 & 74 & 17 & $1137-1534$ & J. Vynckier \\
\hline $\begin{array}{l}\text { Total number of tree-ring series from } \\
\text { altarpiece sculptures }\end{array}$ & 219 & $164(74.8 \%)$ & $55(25.2 \%)$ & & \\
\hline \multicolumn{6}{|l|}{ Panel paintings } \\
\hline Rubens & 19 & 14 & 5 & $1272-1601$ & J. Vynckier \\
\hline Jan Van Eyck & 11 & 11 & - & $1136-1407$ & J. Vynckier \\
\hline Rogier van der Weyden & 5 & 4 & 1 & $1231-1444$ & J. Vynckier \\
\hline Hans Memling & 16 & 15 & 1 & $1099-1525$ & J. Vynckier \\
\hline Pieter Bruegel the Elder & 3 & 3 & - & $1212-1551$ & J. Vynckier \\
\hline Pieter Bruegel the Younger & 5 & 5 & - & $1239-1592$ & J. Vynckier \\
\hline Dirk Bouts & 15 & 14 & 1 & $1173-1543$ & J. Vynckier \\
\hline Various artists & 247 & 200 & 47 & $1023-1640$ & $\begin{array}{l}\text { J. Vynckier; } \\
\text { H. Beeckman \& } \\
\text { K. Haneca }\end{array}$ \\
\hline $\begin{array}{l}\text { Total number of tree-ring series from } \\
\text { panels of panel paintings }\end{array}$ & 321 & $266(82.9 \%)$ & $55(17.1 \%)$ & & \\
\hline
\end{tabular}

these regional chronologies are now supposed to represent a larger area.

While the regional chronologies now cover a larger area, it becomes more likely that individual series show high similarities with more than one regional chronology. When trying to interpret the provenance of an oak specimen it is necessary that the $t_{\mathrm{H}}$-value calculated with one of these regional chronologies should pass a certain threshold, but more important, the $t_{\mathrm{H}}$-value should be significantly higher compared to the other values calculated with the remaining chronologies. There should be only one $t_{\mathrm{H}}$-value that clearly points towards one region.

\subsection{Missing sapwood and felling date estimates}

The majority of the art historical objects lack sapwood, which is more vulnerable to biological degradation by insects and fungi. When the heartwood/sapwood boundary can be identified or when a few sapwood rings are preserved a more precise felling date can be calculated using sapwood estimates for the Baltic area. In all other cases, where all sapwood and an unknown number of heartwood rings have been removed, only a terminus post quem can be calculated by adding the lower limit of the sapwood estimates. Oaks from present-day Poland contain approximately 15 (9-24 in the $90 \%$ confidence interval) sapwood rings [35].

This average number should be added to complete the number of missing sapwood rings on the individual series. For altarpieces it is assumed that all sculptures were carved during the same tight time interval. Therefore, the most recent felling date or terminus post quem, calculated from one particular sculpture from an altarpiece, should be attributed to all sculptures from that altarpiece. This is of course a generalisation and will not be correct for all elements in all objects. Nevertheless, this could be considered an acceptable approximation since the time needed for transportation, seasoning and storage is thought to be short. According to Wazny and Eckstein [37], the time required for a ship to sail from Gdansk to London, and to deliver their goods was less than 1 month, though this was highly dependent on the political situation. Although the medieval guilds prescribed the use of dry timber [13], sculptors preferred freshly cut oak wood to carve their sculptures from. Therefore, the drying period was often reduced to a minimum or neglected at all [17]. In general, no more than 1-4 years elapsed between the logging of a tree and the creation of an altarpiece with wood from that tree (Haneca, unpublished data). For panel paintings this is usually $5 \pm 3$ years [3]. 


\section{Results}

In total 540 tree-ring series from historical art objects from 15 th-16th centuries were collected. Nearly $80 \%$ (430 out of 540) of all the tree-ring series from this art historical database could be dated against standard Baltic master chronologies Baltic1 and Baltic2 [21], and East-Pomerania [19]. Averaging tree-ring series from the same tree, displaying high inter-correlation and excellent visual agreement, reduced the original data set down to 390 series. The total time period covered by the dated series ranges from $1023 \mathrm{AD}$ to $1640 \mathrm{AD}$. The remaining tree-ring series have yet to be dated against any other available master chronology.

In addition to the dendrochronological data, historical records dealing with commerce and politics need consulting. Written documents providing more details on the trade in forest products from the Baltic region before $1562 \mathrm{AD}$ are rare. One of the most important sources that can help to quantify the Baltic timber trade are the Books of the Sound Dues [6]. In these toll books, the cargo of vessels passing through the Sound of Denmark was recorded, from 1562 AD onwards. Together with the type of cargo the harbour of export was also recorded. The most important commodity that was shipped from the Baltic area was grain, but forest products were the second most important commodities exported towards the staple towns of the Hanseatic League [31]. According to these historical toll records, most of the so-called wainscots were shipped from Gdansk, Königsberg and the Dutchy of Courland, i.e. the part of present-day Latvia west of the Daugava River up to the Baltic Sea. Gdansk in particular, at the mouth of the Vistula River, took a dominant position in the timber trade. In 1565 AD up to $85 \%$ of all the wainscots that passed through the sound of Denmark towards the North Sea were shipped from Gdansk (Fig. 3). This percentage dropped to $73 \%$ in $1575 \mathrm{AD}$ and only $53 \%$ in $1585 \mathrm{AD}[6,37]$. It is probable that large quantities of wood, logged after this date, originate from regions further to the northeast. At present, only a few, short and poorly replicated reference chronologies for oak are available from the Baltic States (Estland, Letland, Lithuania) for the period of intensive trade in forest products [26]. This hampers further attempts to locate the timber source in the period after 1585 AD when harbours other than Gdansk become more important. In order to maximize the probability that the original timber source is represented by the data set of site chronologies from present-day Poland, all tree-ring series from the art historical database with felling dates later than 1585 AD were removed. After this elimination process, a total of 348 tree-ring series were available for further analysis.

Tree-ring series from modern forests were used to compute the average $t$-value observed between trees within one forest in Poland. The average $t_{\mathrm{H}}$-value within the nine selected sites ranges from 4.96 to 7.39 , with an overall average value of 5.93 for Poland. This value, rounded to 6.0 , will be considered a guide value, which should be exceeded by the $t_{\mathrm{H}}$-values before any further interpretations will be made concerning the original timber source. The tree-ring series from the modern forest were also averaged into site chronologies. In Table 3, an overview is presented of the correlation, expressed as $t_{\mathrm{H}}$-values, between the modern site chronologies for their common time interval 1871-1984 AD. The overall correlation is very low, and does not seem to depend solely on the geographical proximity of the sites. Only a few neighbouring sites have a considerably high $t_{\mathrm{H}}$-value (e.g. Goldap and Suwalki), whilst other neighbouring sites have a very low $t_{\mathrm{H}}$-value (e.g. Koszalin and Wolin). It is probable that other factors, such as soil type, slope, etc., play a more significant role in the explanation of differences in tree-ring pattern between different sites. This corresponds with a similar comparison

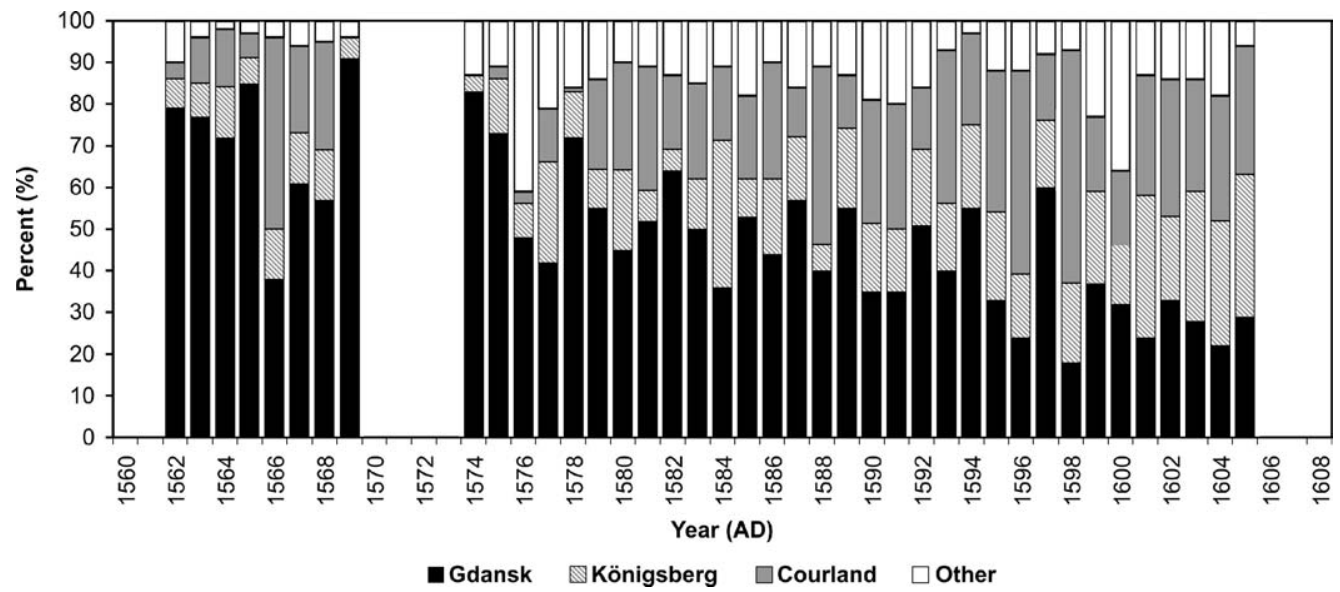

Fig. 3. Percentage of wainscots passing through the Sound of Denmark, shipped from the various Baltic harbours according to Bonde et al. [6]. 
Table 3

Correlations, expressed as $t_{\mathrm{H}^{-}}$values, between modern site chronologies from present-day Poland

\begin{tabular}{|c|c|c|c|c|c|c|c|c|c|}
\hline Site code & pola007 & pola008 & pola009 & pola010 & pola011 & pola013 & pola014 & pola015 & pola016 \\
\hline pola016 & 2.5 & 1.5 & 1.5 & 1.7 & 2.5 & 2.6 & 3.3 & 2.1 & - \\
\hline pola015 & 1.4 & 3.9 & 4.9 & 0.7 & 2.6 & 3.5 & 2.9 & - & \\
\hline pola014 & 2.4 & 3.8 & 3.5 & 3.4 & 3.2 & 2.8 & - & & \\
\hline pola013 & 5.1 & 2.8 & 1 & 0.7 & 0.3 & - & & & \\
\hline pola011 & 0.9 & 3 & 5.9 & 1.9 & - & & & & \\
\hline pola010 & 1.2 & 0.5 & 1.4 & - & & & & & \\
\hline pola009 & 0.3 & 3.9 & - & & & & & & \\
\hline pola008 & 1.9 & - & & & & & & & \\
\hline pola007 & - & & & & & & & & \\
\hline
\end{tabular}

of site chronologies from Britain [7]. A more exhaustive study on the differentiation between forest sites in Poland, with special interest in dendrochronology, has been made by Wazny [35] and Ufnalski [32].

Comparison of the selected series from the art historical database with the site chronologies from Poland resulted in a 348 (no. of individual tree-ring series) $\times 36$ (no. of site chronologies) correlation matrix of $t$-values. In general, the calculated $t_{\mathrm{H}}$-values are rather low. The $t_{\mathrm{H}}$-values peaked above the threshold of 6.0 in only a few cases. Since such a multiple comparison increases the risk for false positive values (i.e. statistical type II errors), it is important to interpret the $t$-values very critically, even when they are high. Therefore, when the high $t$-values are scattered without any geographical order over several sites, no further attempt was made to interpret these. It was observed that in $8.9 \%$ (i.e. for 31 out of 348 series) of all series from the art historical database a high and unique correlation was found with one of the historical site chronologies from Poland.

A wide variety of both hierarchical (between- and within-group linkage, centroid clustering, Ward's method) and non-hierarchical ( $K$-means) statistical clustering techniques have been performed on the modern site chronologies, in order to obtain a statistically reliable grouping of the different sites. All applied statistical procedures delivered very disordered results that were not suited for further interpretation. Therefore, four groups were defined arbitrarily, based on the sites' geographical distribution and associated phytogeographical characteristics (Fig. 2). Groups A and B represent the coastal region of Poland with, adjacent to the south, the lake district called Pomerania. Characteristic for this region is the high humidity, an annual rainfall above $600 \mathrm{~mm}$, mild winters and rare scorching summers. The eastern part encloses Gdansk, the region's commercial, political and cultural centre, located in the mouth of the Vistula River. Group C covers the basin of the middle Vistula and the Mazovian Lowland. In the Middle Ages most of this huge plain was covered by primeval woods. Group D represents the Podlasie Lowland at the confluence of the Narew, Biebrza and Bug Rivers, with large flood plains and Europe's largest natural forest, Puszcza Bialowieska. Characteristic for this part of Poland is the climates strong continental component, which increases eastward.

For each group a regional chronology was computed by calculating the arithmetic mean of all site chronologies enclosed by that group. The regional chronologies now represent a larger and more diverse area than the individual site chronologies. For further comparison, the minimum $t_{\mathrm{H}}$-value was lowered down to 5 (i.e. the lowest average $t_{\mathrm{H}}$-value found for modern forest sites in Poland, see above), but more important, other $t_{\mathrm{H}^{-}}$-values should be at least $25 \%$ lower than the highest $t_{\mathrm{H}}$-value. Only upon meeting both requirements are tree-ring series supposed to be related to a group or region. After comparison of the individual tree-ring series with these chronologies, a further 14 series could be assigned to a certain region. This adds up to $12.9 \%$ of all series that show a distinct correlation with one specific regional or site chronology.

According to the research done by Wazny and Eckstein [38], Poland can also be divided into a northern and a southern part. This is based on a difference in the climatological response of oak trees from the coastal region and the more continental inland. Again, the site chronologies from northern and southern Poland were averaged into two regional chronologies, one for the north and one for the south (Fig. 2). Here 13.8\% (48 out of 348) of all single series showed a significantly high and distinct correlation with one of the two regional chronologies.

The tree-ring series that demonstrated a clear tendency towards one of the four regional chronologies or 36 site chronologies were set aside for further analysis. For each individual series the most precise estimate of the actual felling date was calculated. According to the calculated felling dates, the cumulative number of treering series associated with one regional chronology was computed. These cumulative numbers were plotted on a time axis (Fig. 4). Most of the selected tree-ring series show a clear tendency towards groups $\mathrm{B}, \mathrm{C}$ or $\mathrm{D}$. Particularly the regional chronology of group B, which is composed of tree-ring series from forests in the vicinity of Gdansk, is often designated as the original timber source for several tree-ring series from art historical objects. Only in a few cases were high and unique $t_{\mathrm{H}}$-values for group $\mathrm{A}$ found. 


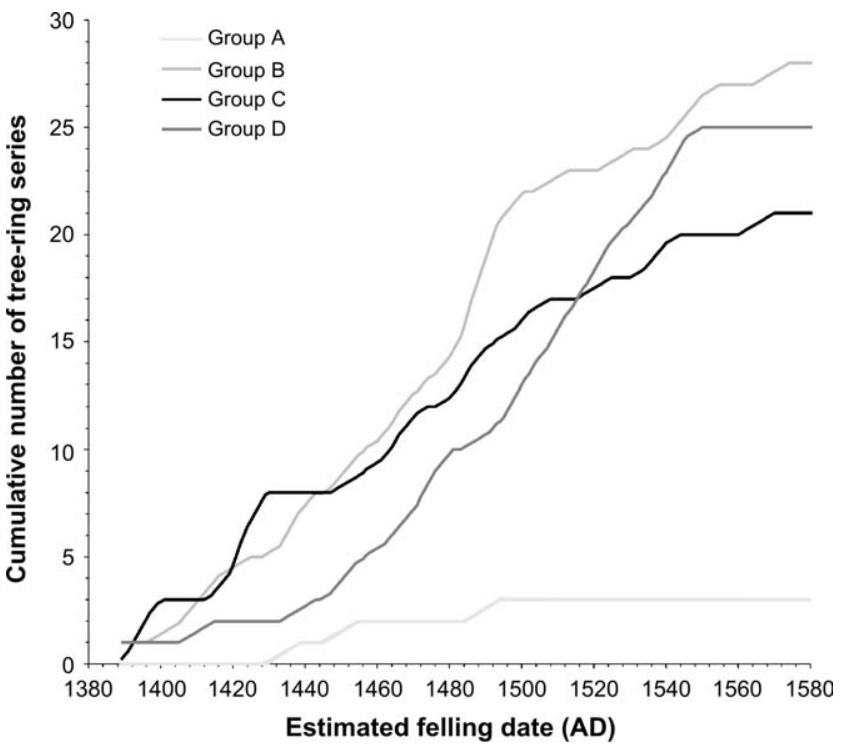

Fig. 4. Cumulative number of art historical tree-ring series attributed to one of the four different regional chronologies (see Fig. 2) for Poland.

\section{Discussion}

All dated tree-ring series from the art historical database showed high $t_{\mathrm{H}}$-values with standard Baltic reference chronologies. For instance, the average $t_{\mathrm{H}}$-value for all dated art historical tree-ring series with the Baltic1 chronology is 6.62. The estimated felling dates from the dated tree-ring series fall within the era of intensive timber trade from regions around the Baltic Sea towards staple towns in England, Flanders and in a later stage Holland. Comparison with other master chronologies from Germany, France, The Netherlands, Denmark or Great Britain did not result in higher $t$-values for any of the series. This suggests that the treering series from the art historical database originate from the same area as the tree-ring series that were used to construct the Baltic reference chronologies. More detailed information on the original timber source cannot be obtained by further comparison with standard Baltic references since these chronologies reflect the growth conditions over vast areas.

Only $8.9 \%$ of the art historical sequences were strongly correlated with only one or few site chronologies in a certain region. It is probable that comparison of individual tree-ring series with site chronologies is too detailed and is a strategy that only in a few cases could lead to the correct interpretation. After grouping site chronologies from four characteristic regions, $12.9 \%$ of the art historical tree-ring series showed a high and distinct correlation with one of the group chronologies. These chronologies represent a larger area, and should have a stronger common signal in their average ring width patterns. When trying to distinguish only between northern and southern Poland, $13.8 \%$ of the individual series could clearly be attributed to one of these regions. So this final distinction between northern and southern Poland does not result in a significantly higher number of tree-ring series that could be attributed to a specific region.

The cumulative numbers demonstrate that the majority of the tree-ring series that display a significantly high and distinct correlation are associated with groups B and $\mathrm{C}$ (Fig. 2). The more or less constant slope of the fitted curves illustrates that these regions were a regular supply area during this period of intensive timber trade. The number of tree-ring series that highly correlate with group $\mathrm{D}$ shows a strong increase after $1450 \mathrm{AD}$. Before that period it is only rare that one of the art historical samples shows a clear tendency towards this area. Another successful application of dendrochronology as a tool to determine the original timber source of imported Baltic oak was reported by Wazny [36]. Treering series of oak panels from the painted ceiling of Guthrie Aisle in Scotland, dated by Crone [9], were also compared with site chronologies from Poland. This resulted in extremely high $t$-values $\left(t_{\mathrm{BP}}>9\right.$; calculated according to the Baillie and Pilcher algorithm [1]) with historical chronologies, composed of wood specimens that probably represent regions adjoining the Bialowieska forest in eastern Poland, near the border with Belarus. This region is covered by the regional chronology of group D. The exact felling date for the painted panels could not be determined, but the trees were certainly felled after 1450 AD. Wood from the northwestern part of Poland, covered by the group A chronology, is seldom found in the art historical database.

The provenance of 45 objects from a set of 348 historical art objects can now be defined more accurately. Their original timber source was previously described as the Baltic region. Now it is possible to be more specific and narrow the source to a particular region in present-day Poland. For the majority of the data set it was not possible to locate more accurately the origin of the timber source. The lack of a sufficient number of site chronologies from southern Poland in this analysis could be one of the main reasons why more tree-ring series could not be attributed to a certain region. However, southern Poland was not the only major timber source. Regions outside present-day Poland, both the Baltic States (Estonia, Latvia and Lithuania) and Belarus have also been major suppliers for the Baltic timber trade [39].

In order to maximize the potential of dendrochronology as a tool to determine the original timber source, often referred to as dendro-provenancing, there are still some aspects that need to be addressed. Despite the progress that has been made during the last decade, more site and regional chronologies that cover the period of the Hanseatic timber trade are needed in 
countries around the Baltic Sea. Such regional oak chronologies, especially in the Baltic States and Belarus, should allow the application of dendrochronology for provenancing purposes in a more detailed and comprehensive way. Unpublished historical documents from archives, dealing with the Hanseatic trade could also help to quantify the amounts of forest products that were transported and document the origin of the traded products. At present, site chronologies cover narrow periods and sometimes hamper clear characterization of the original timber source. Extension of existing site and regional chronologies should facilitate the interpretation of the generated correlation values.

\section{Acknowledgements}

This study was undertaken within the framework of a research project entitled "Methodical and interdisciplinary research on characteristics, evolution and socialcultural significance of the carved altarpieces of Brabant (15th-16th centuries)", funded by the Fund for Scientific Research-Flanders (Belgium). The authors would like to thank Mark Van Strydonck at the Royal Institute for the Study and Conservation of Belgium's Artistic Heritage, who provided the art historical tree-ring series measured by J. Vynckier. We also owe our gratitude to Dr. Niels Bonde, working at the National Museum of Denmark in Copenhagen, for providing tree-ring data and additional information on the historical timber trade in the Baltic region.

\section{References}

[1] M.G.L. Baillie, J.R. Pilcher, A simple crossdating program for tree-ring research, Tree-Ring Bulletin 33 (1973) 7-14.

[2] J. Bauch, Tree-ring chronologies for the Netherlands, BAR International Series 51 (1978) 133-137.

[3] J. Bauch, D. Eckstein, Dendrochronological dating of oak panels of Dutch seventeenth-century paintings, Studies in Conservation 15 (1970) 45-50.

[4] J. Bauch, D. Eckstein, G. Brauner, Dendrochronologische Untersuchungen an Eichenholztafeln von Rubens-Gemälden, Jahrbuch der Berliner Museen 20 (1978) 209-221.

[5] N. Bonde, Dendrochronology and timber trade in northern Europe from the 15th to 17th century, in: T.S. Bartholin, B.E. Berglund, D. Eckstein, F.H. Schweingruber (Eds.), Tree Rings and Environment, Proceedings of the International Dendrochronological Symposium (LUNDQUA Report 34), Ystad, Sweden, 3-9 September 1990, Lund University, Lund, 1992, pp. 53-55.

[6] N. Bonde, I. Tyers, T. Wazny, Where does the timber come from? Dendrochronological evidence of the timber trade in Northern Europe, in: A. Sinclair, E. Slater, J. Gowlett (Eds.), Archaeological Sciences 1995, Oxbow Monograph 64, 1997, pp. 201-204.

[7] M.C. Bridge, Can dendrochronology be used to indicate the source of oak within Britain? Vernacular Architecture 31 (2000) 67-72.

[8] J. Buis, Historia Forestis: Nederlands bosgeschiedenis, HES Uitgevers B.V., Utrecht, 1985.
[9] A. Crone, The dendrochronological analysis of panels from the painted ceiling of Guthrie Aisle, AOC ref: 1773 (1998) 7 pp.

[10] A. Crone, R. Fawcett, M. Hall, A group of late medieval carved wooden panels in Perth Museum and Art Gallery - their provenance and date, Tayside and Fife Archaeological Journal 6 (2000) 189-199.

[11] U.M. Csaikl, I. Glaz, V. Baliuckas, R.J. Petit, J.S. Jensen, Chloroplast DNA variation of white oak in the Baltic countries and Poland, Forest Ecology and Management 156 (2002) 211222.

[12] R. De Boodt, Retabelkasten, ornamentiek en beeldsnijwerk, Onderzoek naar de mate van formele standaardisatie in de Antwerpse retabelproductie van de zestiende eeuw, PhD Dissertation, Vrije Universiteit Brussel, Brussels, 2004.

[13] R. De Boodt, K. Haneca, H. Cuvelier, Reconstruction and deconstruction. Interdisciplinary research on the altarpieces of Bassine, Pailhe and Gaasbeek, in: C. Van de Velde, J. Van Acker, H. Beeckman, F. Verhaeghe (Eds.), Constructing Wooden Images: Proceedings of a Symposium on the Organization of Labour and Working Practices of Late Gothic Carved Altarpieces in the Low Countries, Brussels 25-26 October 2002, VUB Press, Brussels, in press.

[14] D.J. de Vries, Bouwen in de late Middeleeuwen: stedelijke architectuur in het voormalige Over-en Nedersticht, PhD Dissertation, Rijksuniversiteit Leiden, Leiden, 1994.

[15] M.-F. Deguilloux, M.-H. Pemonge, R.J. Petit, Novel perspectives in wood certification and forensics: dry wood as a source of DNA, Proceedings of the Royal Society of London, Series B: Biological Sciences 269 (2002) 1039-1146.

[16] S. Dumolin-Lapègue, M.-H. Pemonge, L. Gielly, P. Taberlet, R.J. Petit, Amplification of oak DNA from ancient and modern wood, Molecular Ecology 8 (1999) 2137-2140.

[17] D. Eckstein, Wood science and art history-interdisciplinary research illustrated from a dendrochronological point of view, in: C. Van de Velde, J. Van Acker, H. Beeckman, F. Verhaeghe (Eds.), Constructing Wooden Images: Proceedings of a Symposium on the Organization of Labour and Working Practices of Late Gothic Carved Altarpieces in the Low Countries, Brussels 25-26 October 2002, VUB Press, Brussels, in press.

[18] D. Eckstein, J.A. Brongers, J. Bauch, Tree-ring research in The Netherlands, Tree-Ring Bulletin 35 (1975) 1-13.

[19] D. Eckstein, T. Wazny, J. Bauch, P. Klein, New evidence for the dendrochronological dating of Netherlandish paintings, Nature 320 (1986) 465-466.

[20] P. Fraiture, Contribution of scientific methods to the understanding of the work on the 16th century painter, Henry Bles, Dendrochronologia 20 (3) (2002) 285-299.

[21] J. Hillam, I. Tyers, Reliability and repeatability in dendrochronological analysis: tests using the Fletcher archive of panelpainting data, Archaeometry 37 (2) (1995) 395-405.

[22] E. Hollstein, Mitteleuropäische Eichenchronologie, Verlag Phillipp von Zabern, Mainz am Rhein, 1980.

[23] D. Houbrechts, M. Pieters, Tonnen uit Raversijde (Oostende, prov, West-Vlaanderen): een goed gedateerd verhaal over water- en andere putten, Archeologie in Vlaanderen V (1996) 225-261.

[24] M. Kaennel, F.H. Schweingruber, Multilingual Glossary of Dendrochronology, Terms and Definitions in English, German, French, Spanish, Italian, Portuguese and Russian, Paul Haupt, Birmensdorf, 1995.

[25] R.J. Petit, U.M. Csaikl, S. Bordàcs, K. Burg, E. Coart, J. Cottrell, B. van Dam, J.D. Deans, S. Dumolin-Lapègue, S. Fineschi, R. Finkeldey, A. Gillies, I. Glaz, P.G. Goicoechea, J.S. Jensen, A.O. König, A.J. Lowe, S.F. Madsen, G. Mátyás, R. Munro, M. Olalde, M.-H. Pemonge, F. Popescu, D. Slade, H. Tabbener, D. Taurchini, S.G.M. de Vries, B. Ziegenhagen, A. Kremer, Chloroplast DNA variation in European white oaks. Phylogeography and patterns of diversity based on data from over 
2600 populations, Forest Ecology and Management 156 (2002) 5-26.

[26] R. Pukiené, Oak annual radial growth chronology covering 12081408, Dendrologia Lithuaniae VI (2002) 102-107.

[27] O. Rackham, The growing and transport of timber and underwood, in: S. McGrail (Ed.), Woodworking techniques before A.D. 1500, BAR International Series, Oxford, 1982, pp. 199-217.

[28] O. Rackham, Ancient woodland: its history, vegetation and uses in England, Castlepoint Press, Dalbeattie, 2003.

[29] R. Rybarski, Handel i polityka handlowa Polski w XVI wieku, PWN, Warszawa, 1958.

[30] G. Tack, P. van den Bremt, M. Hermy, Bossen van Vlaanderen, Een historische ecologie, Davidsfonds, Leuven, 1993.

[31] J. Tossavainen, Dutch forest products' trade in the Baltic from the Late Middle Ages to the peace of Munster in 1648, Master Thesis, University of Jyväskylä, Department of History, Jyväskylän, 1994.

[32] K. Ufnalski, Porownanie dynamiki przyrostu dębu szypulkowego i bezszypulkowego ze szczególnym uwzględnieniem okresow zamierania, PhD Dissertation, Polish Academy of Sciences, Institute of Dendrology, Kórnik, 2001.
[33] F.W.M. Vera, Grazing ecology and forest history, CABI Publishing, Wallingford, 2000.

[34] J. Vynckier, Toelichting bij het dendrochronologisch onderzoek van enkele Antwerpse gebeeldhouwde retabels uit de 15de en 16de eeuw, in: H. Nieuwdorp (Ed.), Antwerpse Retabels, 15de-16de eeuw, Exposition Catalogue, Kathedraal Antwerpen, Antwerp, 1993, pp. 189-191.

[35] T. Wazny, Aufbau und Anwendung der Dendrochronologie für Eichenholz in Polen, PhD Dissertation, University of Hamburg, Hamburg, 1990.

[36] T. Wazny, Baltic timber in Western Europe-an exciting dendrochronological question, Dendrochronologia 20 (3) (2002) 313-320.

[37] T. Wazny, D. Eckstein, Der Holzhandel von Danzig/GdanskGeschichte, Umfang und Reichweite, Holz als Roh- und Werkstoff 45 (1987) 509-513.

[38] T. Wazny, D. Eckstein, The dendrochronological signal of oak (Quercus sp.) in Poland, Dendrochronologia 9 (1991) 35-49.

[39] M. Zunde, Timber export from medieval Riga and its impact on dendrochronological dating in Europe, Dendrochronologia 16-17 (1999) 119-130. 